\title{
Targeting the Human CD3 $\gamma$ Gene Promoter By HIV-I and HTLV-I: Two Distinct Mechanisms Involving A Transcriptional Regulatory Element and Chromatin Remodeling
} KE Willard-Gallo* ${ }^{*}$, BM Badran ${ }^{1}, \mathrm{H} \mathrm{Akl}^{1}$, M Ravoet ${ }^{1}$, G Dorbrita ${ }^{1}$, G Manfouo-Foutsop ${ }^{1}$, C Equeter ${ }^{1}$, A Burny ${ }^{1}$, K Kunstman ${ }^{2}$, J Stanton ${ }^{2}$ and SM Wolinsky²

Address: ${ }^{1}$ University of Brussels (ULB), Bordet Institute, Brussels, Belgium and ${ }^{2}$ Northwestern University Medical School, Chicago, IL

Email: KE Willard-Gallo* - kwillard@dbm.ulb.ac.be

* Corresponding author $\ddagger$ Presenting author

from 2005 International Meeting of The Institute of Human Virology

Baltimore, USA, 29 August - 2 September 2005

Published: 8 December 2005

Retrovirology 2005, 2(SuppI I):SI I3 doi:I0.I I86/I742-4690-2-SI-SII3

Our studies show that HIV-1, HIV-2, and HTLV-I infection all provoke a progressive defect in surface $\mathrm{T}$ cell receptor expression. A specific loss of CD $3 \gamma$ transcripts is responsible for the defect after HIV-1 or HIV-2 infection. Alternatively, while CD3 $\gamma$ transcripts are lost first after HTLV-I infection, their reduction is followed several months later by a loss of CD $3 \delta$ and subsequently CD $3 \varepsilon$ mRNA. Studies of $\mathrm{CD} 3 \gamma$ transcriptional control revealed parallels with elements regulating HIV-1 gene expression, including a downstream element reminiscent of HIV TAR. Mutant and deletion CD3 $\gamma$ promoter constructs delimited a $53 \mathrm{bp}$ region downstream from the major transcription start site as critical for positive gene expression. EMSA experiments demonstrate that this sequence functions through an RNA rather than a DNA intermediate, which can bind three specific nuclear protein complexes. Deletion of $U$ at +9 and +37 kills promoter activity. Alternatively, progressive silencing of the CD3 gene locus by HTLV-I functions via chromatin remodeling, characterized by increased binding of Ikaros to the CD3 $\gamma$ promoter and the $\mathrm{CD} 3 \delta$ enhancer. Expression of the CD3 genes can be reactivated in HTLV-I infected cells by the synergistic action of the histone deactylase inhibitor trichostatin $\mathrm{A}$ and the DNA methyltransferase inhibitor 5-aza-2'-deoxycytidine. The importance of viral targeting of the $\mathrm{CD} 3$ genes will be discussed. 